\title{
Tell-tale Landscapes and Mythical Chronotopes in Urban Designs for Twenty-first Century Paris
}

\author{
Bart Keunen \\ Ghent University \\ Sofie Verraest \\ Ghent University
}

Follow this and additional works at: https://docs.lib.purdue.edu/clcweb

¿

Part of the Comparative Literature Commons, and the Critical and Cultural Studies Commons

Dedicated to the dissemination of scholarly and professional information, Purdue University Press selects, develops, and distributes quality resources in several key subject areas for which its parent university is famous, including business, technology, health, veterinary medicine, and other selected disciplines in the humanities and sciences.

CLCWeb: Comparative Literature and Culture, the peer-reviewed, full-text, and open-access learned journal in the humanities and social sciences, publishes new scholarship following tenets of the discipline of comparative literature and the field of cultural studies designated as "comparative cultural studies." Publications in the journal are indexed in the Annual Bibliography of English Language and Literature (Chadwyck-Healey), the Arts and Humanities Citation Index (Thomson Reuters ISI), the Humanities Index (Wilson), Humanities International Complete (EBSCO), the International Bibliography of the Modern Language Association of America, and Scopus (Elsevier). The journal is affiliated with the Purdue University Press monograph series of Books in Comparative Cultural Studies. Contact: <clcweb@purdue.edu>

\section{Recommended Citation}

Keunen, Bart; and Verraest, Sofie. "Tell-tale Landscapes and Mythical Chronotopes in Urban Designs for Twenty-first Century Paris." CLCWeb: Comparative Literature and Culture 14.3 (2012): <https://doi.org/10.7771/1481-4374.2038>

This text has been double-blind peer reviewed by $2+1$ experts in the field.

The above text, published by Purdue University Press @Purdue University, has been downloaded 715 times as of $11 /$ $07 / 19$.

This document has been made available through Purdue e-Pubs, a service of the Purdue University Libraries. Please contact epubs@purdue.edu for additional information.

This is an Open Access journal. This means that it uses a funding model that does not charge readers or their institutions for access. Readers may freely read, download, copy, distribute, print, search, or link to the full texts of articles. This journal is covered under the CC BY-NC-ND license. 


\title{
PURDUE
}

U N I V E R S I T Y UNIVERSITY PRESS < http://www.thepress.purdue.edu>

\section{CLCWeb: Comparative Literature and Culture}

ISSN 1481-4374 <http://docs.lib.purdue.edu/clcweb> Purdue University Press @Purdue University

CLCWeb: Comparative Literature and Culture, the peer-reviewed, full-text, and open-access learned journal in the humanities and social sciences, publishes new scholarship following tenets of the discipline of comparative literature and the field of cultural studies designated as "comparative cultural studies." In addition to the publication of articles, the journal publishes review articles of scholarly books and publishes research material in its Library Series. Publications in the journal are indexed in the Annual Bibliography of English Language and Literature (Chadwyck-Healey), the Arts and Humanities Citation Index (Thomson Reuters ISI), the Humanities Index (Wilson), Humanities International Complete (EBSCO), the International Bibliography of the Modern Language Association of America, and Scopus (Elsevier). The journal is affiliated with the Purdue University Press monograph series of Books in Comparative Cultural Studies. Contact: <clcweb@purdue.edu>

\section{Volume 14 Issue 3 (September 2012) Article 4 Bart Keunen and Sofie Verraest, "Tell-tale Landscapes and Mythical Chronotopes in Urban Designs for Twenty-first Century Paris" <http://docs.lib.purdue.edu/clcweb/vol14/iss3/4>}

Contents of CLCWeb: Comparative Literature and Culture 14.3 (2012)

Thematic Issue New Work on Landscape and Its Narration

Ed. Sofie Verraest, Bart Keunen, and Katrien Bollen $<$ http://docs.lib.purdue.edu/clcweb/vol14/iss3/>

\begin{abstract}
In their article "Tell-tale Landscapes and Mythical Chronotopes in Urban Designs for Twenty-first Century Paris" Bart Keunen and Sofie Verraest outline a methodology for the examination of narrative structures projected onto landscapes and exemplify it by analyzing four urbanist projects submitted for the international workshop for Greater Paris launched by President of France Nicholas Sarkozy in 2009. Keunen and Verraest focus on phantasmagorical urban spaces considered to be profane remnants of what Ernst Cassirer referred to as "mythical thought." Since the spatiotemporal structure of these phantasmagorical places is understood as fundamental to their affective appeal and seductiveness, they are treated as Bakhtinian "chronotopes." Four chronotopes - the oasis, the capsule, the hub, and the bazaar - are thus exposed as the cornerstones of urbanists' rhetoric strategies.
\end{abstract}


Bart Keunen and Sofie Verraest,

"Tell-tale Landscapes and Mythical Chronotopes in Urban Designs for Twenty-first Century Paris" page 2 of 11

CLCWeb: Comparative Literature and Culture 14.3 (2012): <http://docs.lib.purdue.edu/clcweb/vol14/iss3/4>

Thematic Issue New Work on Landscape and Its Narration. Ed. Sofie Verraest, Bart Keunen, and Katrien Bollen

\section{Bart KEUNEN and Sofie VERRAEST}

\section{Tell-tale Landscapes and Mythical Chronotopes in Urban Designs for Twenty-First Century Paris}

In the present study we take our point of departure from the idea that a perceived space is always also an evaluated space. To the human eye, landscape is never the raw and neutral material it is "out there," but always takes on a specific form according to the values it is associated with. When inquiring into these evaluations of landscapes, it proves advantageous to turn to the work of Ernst Cassirer who was not only aware that the human environment is first and foremost a matter of mental modeling, but also provided a systematic account of the different ways in which this modeling occurs. Cassirer distinguished three epistemological forms which enable this act of evaluation on a daily basis: Ausdruck, Darstellung, and Bedeutung (see The Phenomenology). In this article, we designate Cassirer's concepts as the "affective," the "representational," and the "conceptual" epistemological form, respectively. By considering not only the "conceptual," but also the "affective" and the "representational" to be forms of thought, Cassirer draws attention to the fact that our knowledge of the outside world is far from being rational and logical at all times and that such consistent knowledge in fact merely constitutes the ulterior phase of a very gradual movement towards abstraction. An array of anthropological studies supports Cassirer's claim that the earliest, most elementary form of thought is one that would be considered rather thought-less today: the direct, emotional evaluation of the environment as an affectively charged space. It is only through a movement towards abstraction that human beings do not only see an "affective" space anymore, but also a stable world of discrete objects that could be labeled "representational" space. The volatile world of emotional tonalities is now supplemented by a world of stable objects that imposes a formal order and coherence. So-called "thing perception" sets in (Cassirer, The Phenomenology 118-41), which pertains simply to the visual perception of things, persons, buildings, or landscapes as we know it from daily life. Further abstraction brings us to "conceptual" knowledge of the world, which aims for theoretical consistency. Taking even more distance from what we perceive, we no longer consider entities in and by themselves, but instead evaluate them as mere embodiments of an abstract idea or conceptual system; they become objects of theoretical reflection. In sum, three kinds of increasingly abstract cognitive interventions mediate our contact with spatial reality and help us to give meaning to the world surrounding us - whether through emotions, "thing perception," or concepts. While specific cultures may privilege one kind of intervention over another - as is the case for the conceptual one in modern times, for instance, or the affective one at the "primitive" stage - all three are at work in every culture. For the concrete "thing perception" of our spatial environment this means that the mental image into which it crystallizes is colored by both emotional and conceptual values. Following the above postulates, we analyze the spatial images of four proposals submitted for the international atelier of Greater Paris - a 2009 initiative by President of France Nicholas Sarkozy which called for urbanist projects that envision a post-Kyoto Paris integrating its fringes (see Le Grand Paris). We approach the spatial images of the urbanists' Paris-to-come as embodying affective connotations as well as conceptual associations. The emphasis is on affective expressivity, however, which turns the spatial image into an experiential, vivid, and alluring "scene" we consider to be narrative. Central to our narratological understanding of spaces is Mikhail Bakhtin's notion of the chronotope. For Bakhtin, a story is not composed of words or phrases, but of imagined entities: mental images that constitute already-evaluated accounts of the fictional world (see, e.g., Keunen). Since we structure these cognitive images in time and space, Bakhtin calls them "chronotopes." That Bakhtin read, was influenced by, and even plagiarized Cassirer's work has already been demonstrated (see Poole and Brandist), but his writings on the chronotope, too, allow for parallels with Cassirer and, indeed, may benefit from these. If we follow Cassirer and consider the chronotope from an epistemological perspective as a tripartite entity, it can function as the cornerstone of a systematic methodology for examining evaluated time-spaces. For Bakhtin, as well as Cassirer - who is, after all, a neo-Kantian philosopher - time and space make up the axes of our mental construction of the world. This type of spatiotemporal world-making is particularly foregrounded, then, when virtual worlds are imagined - in urbanism or in literature, for instance. Bakhtin argues polemically that "any and every literary image is chronotopic. Language, as a treasure-house of images, is fundamentally 
Bart Keunen and Sofie Verraest,

"Tell-tale Landscapes and Mythical Chronotopes in Urban Designs for Twenty-first Century Paris" page 3 of 11

CLCWeb: Comparative Literature and Culture 14.3 (2012): <http://docs.lib.purdue.edu/clcweb/vol14/iss3/4>

Thematic Issue New Work on Landscape and Its Narration. Ed. Sofie Verraest, Bart Keunen, and Katrien Bollen

chronotopic" (251). Thus, what narrative world-making does is develop scenes by endowing spatial situations with a temporal dynamics.

What is more, given that narrative imagination by far exceeds the limits of literature, and is a fullfledged form of thought that is spontaneously applied in daily life as well (see Bruner; Herman), this chronotopic world-making may well be at work in the way we mentally evaluate our quotidian surroundings. In that sense, perceived and conceived spaces can be seen as narrative chronotopes operating on the three levels discerned in Cassirer's epistemology. On the first level, the chronotope is an experiential entity: it has an affective component. According to David Herman, one of the four basic aspects of narrative is that it is "a mode of representation tailor-made for gauging the felt quality of lived experiences" (137-38). This is what we could call the "immersive" aspect of narrative (see also Ryan, Narrative), which creates intimately experienced narrative "scenes." Second, the chronotope is a Cassirerian "representation": it is a mental image with a specific coherence, a spatiotemporal structure. As such, it is an instrument for "world-making," which, according to Herman, constitutes a second fundamental element of narrative (105-36). Third, the chronotope can play a key role in a more encompassing story or plot. In this case, it is part of what we could call a "conceptual" narrative, in reference to Cassirer's conceptual epistemological form. Bakhtin signals that a chronotope sometimes "fulfills architectonic functions" in the storyline, and thus becomes a device for "structuring a plot" (98). Herman calls this architectonic element of narrative "event sequencing": narrative "cues interpreters to draw inferences about a structured time-course of ... events" (14). Embedded in a broader story development, the lived fictional "scene" of the chronotope acquires a more abstract and symbolic meaning. It becomes an element in the communication between a narrator and a reader or narratee - or in terms of urban design: between the urbanist and the perceiver of the urban spaces he envisions. The chronotope thus becomes part of a conceptual act of evaluation: it is seen to represent a particular stage in a more general socio-historical development. As Arnold Bartetzky and Marc Schalenberg note, "architecture and urban planning have played a prominent role in concepts aiming to achieve happiness by means of changing living conditions ... urban projects have often been conceived and staged as model islands, in anticipation of a bright(er) future for a city, a country or even the whole of humanity" (7). Urban projects, in other words, are not only designed as places that are to be experienced, but they can also be "model islands" that embody more general, conceptual views on human life in the city. However, in what follows, our focus is on immersive urban "scenes" depicting Paris rather than on broader socio-historical stories about cities in general and for a specific reason, which is to be found in Cassirer's Mythical Thought.

Cassirer's writings on what he calls "mythical thought" show that affective scenes have a specific power of attraction that conceptual legitimization cannot have. An urbanist's narrative rhetoric will be particularly convincing if he depicts spaces that are shown to be intensively experienced by their users, and enjoyed to the fullest. As lived spaces, they are highly emotionally charged and "speak to us" on a pre-rational level. They exude an alluring atmosphere that lends them a phantasmagoric or eutopian splendor, making conceptual arguments if not superfluous, then at least optional. Following Cassirer, these emotionally seductive images can be considered present-day, profane variants of socalled "mythical thought," the most ancient and irrational form of thought that occupied center stage in "primitive" societies, and persists today as an elementary layer of consciousness. In "primitive" cultures, emotional evaluations of the environment are, indeed, of essence since a magical, supernatural significance is attached to them. While magical sense-making has evidently lost all credibility in "rationalized" modern societies, it nevertheless resurfaces in all kinds of pre-rational superstition, as well as everyday forms of magical enchantment and idealization. One such example is that of the alluring, eutopian urban images we analyze. Although nearly all urbanist teams profess to a matter-of-fact pragmatism of small-scale intervention and openly reject the grand narrative (see Lyotard) of reinventing the city as pointless utopian idealism sparked by unbridled ambition or blind romanticism, all of this is to be situated on a rational level. It does not prevent certain portrayals of their future Paris from showing signs of a pre-rational, mythical-magical re-enchantment, a kind of "return of the repressed." Many of the urban scenes representing a better Paris have a direct emotional magnetism because they respond to certain irrational dreams or desires. In these specific cases, narrative chronotopes become powerful rhetorical devices in urbanists' discourses - often 
more so than post factum rationalizations of their proposed intervention. We refer to those chronotopes which embody dreamt-of-worlds lingering in the pre-rational layers of consciousness as "mythical." The analysis of these chronotopes or "modern myths" that are projected onto Paris allows us to reveal the narrative rhetoric that underpins urbanists' most evocative discourses and alluring images.

It remains to be explored how we can recognize such mythical chronotopes in concrete terms on both the affective and the representational level. As far as their affective quality goes, a peculiar subjectivization or fetishization of the landscape is essential. If a dark forest seems to breathe a menacing atmosphere and a charming house exudes one of conviviality and safety, this divergence is to be situated on the level of "affective" space. From a mythical (or "primitive") point of view, the affective atmosphere of spaces is particularly significant, because for the mythical human emotions do not originate from himself/herself; they are magical spirits taking possession of him/her, as well as of certain objects or places. That is why trees, amulets, and other fetish objects are considered to be truly animate entities. From this perspective, the world is not so much "a reality of things, of mere objects" as "a kind of presence of living subjects" (Cassirer, The Phenomenology 62). Cassirer refers to this phenomenon as the perception of a "thou" rather than an "it," an animated rather than an objective reality (The Phenomenology 63). As long as no distance is introduced between perceiver and perceived, the subject does not yet distinguish itself from an environment of objects, and still perceives living subjects (spirits) rather than inanimate matter. The mythical way to make sense of the world is thus in terms of magical presence, a presence of subjects.

Cassirer points out that while we do not believe in spirits anymore, we still tend to spontaneously "read" the atmosphere of a specific place as a so-called "physiognomic character," as a facial expression (The Phenomenology 68). We remain inclined to see inanimate objects as "inspired" and alive when they stir certain emotions. We "read" a charming landscape - or to use an expression that is telling enough, a "smiling" landscape - as an expression of inherent kindness, as if it had a friendly soul. As a result, we feel safe in the landscape, like we would when we see a smiling face. In other words, the atmosphere seems to emanate from the place itself. That is why Cassirer speaks of affective "expressions" rather than "impressions": the affect seems to stem from the perceived space rather than from its observer. In line with Max Weber and Walter Benjamin, Cassirer points out that in the largely disenchanted context of "rationalized" societies, aesthetic experiences in particular are highly expressive, and seem to have adopted the role that magic used to play (see O'Toole): beauty still enchants today. With his notions of the "phantasmagorical" and the "auratic" experience, Benjamin was perhaps the most convincing theorist of such on-the-spot re-enchantments or aestheticizations of our surroundings. Although this rapprochement deserves to be discussed at greater length, here we limit ourselves to Cassirer's thoughts on the subject. Following the latter, powerful aesthetic stimuli can be seen as profane remnants of animist powers, which seem to cast their spell and create extraordinary spaces that are set apart from a banal and disenchanted world of functionalism and cold, utilitarian rationality. Places with a strong aesthetic appeal seem to be animated or enchanted by a positive "spirit" or "soul." As the positivity of the image comes from a benevolent magical spirit simply "taking over" in a direct and all-encompassing manner, it does not need, and cannot have, any further explanation as to where it should come from. Cassirer speaks of the "direct efficacy" of the magical. From a purely logical viewpoint, change is conditional: certain conditions need to be met in order for a wished-for change to take place. As a causal chain, change is thus divided into the intermediary steps that make up its successive conditions. From a mythical viewpoint, however, change occurs when magical forces take possession of an object or place. Change cannot be conditional if the forces causing it are supernatural. They manifest themselves with the sort of magical force that guarantees immediate impact: they simply cast a spell on reality. The mode of change, the intermediary steps between wish and fulfillment, between desire and realization, are not analyzed; "between the mere wish and its goal," no "intermediary links are interpolated" (Cassirer, Mythical 158).

This brings us to the second question which needs to be considered in this respect: what is typical of mythical chronotopes (in casu urban images) on the representational level? Cassirer points out that "what seems to remain as the relatively solid core" of the mythical "is simply the impression of the extraordinary, the unusual, the uncommon" (Mythical 77). This "expressive meaning attaches to perception itself, in which it is apprehended and immediately experienced" (68). In other words, the affective impression of the unusual that is typical for mythical thinking directly permeates spatial 
Bart Keunen and Sofie Verraest,

"Tell-tale Landscapes and Mythical Chronotopes in Urban Designs for Twenty-first Century Paris" page 5 of 11

CLCWeb: Comparative Literature and Culture 14.3 (2012): <http://docs.lib.purdue.edu/clcweb/vol14/iss3/4>

Thematic Issue New Work on Landscape and Its Narration. Ed. Sofie Verraest, Bart Keunen, and Katrien Bollen

"representations" or images. From a mythical perspective, this means that concrete objects and places are viewed in terms of the presence or absence of affective magical forces. Along the lines of this distinction, the environment is molded into mythical representations. Some objects and places present themselves to the mythical consciousness with such extraordinary force that they seem magical or sacred, and detach themselves as particularly meaningful from their indifferent surroundings. As such, spatial representation distinguishes between enchanted, affectively charged, extraordinary places, on the one hand, and indifferent, profane ones, on the other: "All reality and all events are projected into the fundamental opposition of the sacred and the profane" (75). Places that are considered to be sacred and magical are set apart from their profane surroundings as "inside" spaces differing from "the outside." Cassirer writes that "hallowing begins when a specific zone is detached from space as a whole, when it is distinguished from other zones and ... religiously hedged around" (Mythical 99). Mythical perception, in other words, is characterized by a logic of "inside and outside," "inward and outward" (99). Likewise, contemporary spaces that have a strong aesthetic allure are still singled out from the ordinary world as seemingly "enchanted" zones. Aesthetic rapture evokes a direct affect of the extraordinary and, with it, an inside/outside contrast. Such is the effect of the most suggestive and rhetorical images conjured up by the urbanist teams: instead of "religiously hedging around" spaces, to borrow Cassirer's expression quoted above, they seem to be hedging them around "aesthetically."

In sum, what makes a narrative chronotope mythical is the direct, magical efficacy with which the space in question acquires an overall positive glow extending to all of its facets, an utterly positive "physiognomy" that gives it a dream-like, enchanting quality and detaches it as an "inside" space from the ordinary, disenchanted "outside world." As if by magic, any and every aspect of the urban situation appears as marvelous in this picture-perfect scene; every possible urban problem seems to be resolved - even if we could rationally object that much more specific measures need to be taken in order for improvement, let alone perfection, to be achieved. In the Paris proposals, for instance, the indisputable social problems of the banlieues often fail to be addressed from a pragmatic point of view, despite the fact that a solution for the suburbs constituted one of the two focal points of the whole exercise. In many of the images portraying the future Parisian suburbs, the social problems simply seem to have dissolved into the wondrous, overall positive physiognomy the space acquires. In his essay on the chronotope, Bakhtin, too, displays an acute sensitivity to this type of extraordinary physiognomic scenes. His "idyllic chronotope" (225), for instance, which constitutes an archetype of literary imagination, is said to have a particular spatiotemporal structure that gives it the affective appeal of an "inside" space. We mention it here because it bears resemblance to our first case study, the Paris vision of the Agence Grumbach.

Bakhtin describes the idyll as a harmonious, enclosed space that can only be maintained by a regular, cyclical time rhythm; the cycles of the seasons, day and night, sowing and harvesting, death and rebirth permeate the landscape: "The mark of ... cyclical repetitiveness is imprinted on all events" (210) and gives the landscape the inviting "face" or atmosphere of a reassuring place of security and belonging. Much of the persuasive imagery of the future Paris depicted by the Grumbach group evokes an atmosphere similar to that of Bakhtin's idyllic chronotope. At times, the group's "Seine metropolis" project comes close to the Arcadian archetype of the enclosed space where one can lead a simple and regular life in harmony with nature and, as such, acquires a wholly positive physiognomy. The idea is to create a Greater Paris that would stretch from today's city along the valley of the Seine up to Le Havre, where a large inland port would emerge - "Paris Rouen Le Havre as one and the same city, with the Seine as its main street" (Agence Grumbach, Livret 211 ; unless indicated otherwise, all translations are ours). In line with earlier utopian notions of linear cities arranged around rivers, Greater Paris would thus be united in and by the Seine valley: "The global city is nourished by its river, and its inhabitants' daily life cannot be extricated from a poetic relationship with the river" (Agence Grumbach, Livret 2 17). All hope seems to be set on the salutary effect of the stream that is to "irrigate" the entire valley of Greater Paris. Since it is the Seine that can unite and harmonize Paris into a circular ecosystem, the atelier argues, the city will be irredeemably lost if its development is not organized around this vital force: "As soon as the city ceases to function in the cyclic way of biological ecosystems, it enters the stage of degradation (catabolism)" (Agence Grumbach, Livret 2 77). A city 
united around the Seine, by contrast, "irrigates its inhabitants with all the flows it needs ... to nourish its body and mind, and flourish," as if by magic (Agence Grumbach, Livret 2 77). How exactly the "unification" around the river could guarantee the overall development of the Parisians is not clear: to a certain extent the team seems to "expect" the vital force of the stream to simply cast its spell on reality at which point everything would be in its power. It seems to be an all-or-nothing situation: if we allow a positive spirit to come over Paris by letting the Seine exert its direct unifying powers, all will be good; in the alternative case, all might be lost.

Time and again, the Grumbach group's imagery presenting the river as the vital axis and lifegiving force of a balanced existence in harmony with nature's cycles appears as a near-textbook example of Bakhtin's idyllic chronotope. According to Atelier Grumbach, what is needed is a way to "think in a more circular fashion, by harmonizing our actions, our economies, our respect for nature ... In a sense, we need to retrieve 'our true nature,' as the popular expression goes" (Livret 2 77). Organized around the Seine, the city of Paris becomes an autarkic system, a closed circle (Une Métropole <http://www.linternaute.com/actualite/grand-projet/photo/grand-paris-voici-ce-qu-ontprevu-les-architectes/une-metropole-geante-de-paris-au-havre.shtml>). Ultimately, this cyclic time rhythm even marks the group's conception of economy, which bears similarities to the collective work of a genuine community: "The interweaving of activities ensures a circular economy, in the manner of biological ecosystems ... there is no served space in a serving space anymore, only the pursuit of equilibrium between spaces" (Agence Grumbach, Livret 18 ). Such a representation of today's economy can hardly be explained without taking into account the somewhat mythical inspiration of the urban space envisioned. Economy is made to partake in the circularity that is supposed to unite Greater Paris as a privileged community distancing itself from mediocrity, a singular landscape that acquires the poetic expressivity of an exceptional spatiotemporal "inside." What is actually depicted is the beneficent experience of being part of a privileged collectivity and unity. We put forth the metaphor of the "oasis" to capture this first chronotopic "dream." It is the place where Berbers meet and bonds are forged, where harmonious relations are established in the middle of a vast desert that has nothing else of the kind to offer - a fertile "inside" separated from the barren "outside."

A second kind of re-enchanting chronotope is primarily found in the project of the Atelier LionGroupe Descartes. Like the oasis, the chronotope under consideration is characterized by an enclosed, integrated space that forms a unity, as well as by a predictable time pattern. In addition, the regular and wholly manageable world of this chronotope, too, exudes an atmosphere of security - as if one were sheltered from "the big bad world" in it. What is different about the second chronotope, however, is that the united, regular space is no longer one of collectivity, but a private zone for the individual. Whereas the oasis sought to transform the urban complexity into a manageable, repetitive sphere, the present chronotope seems to take it as irremediable and idyllic elements now serve to create an environment in which to withdraw from this chaotic "outside." We propose to refer to this zone of withdrawal as a "capsule." The desire for belonging and security that propels it is no longer captured in an ecumenical dream, but in a more aesthetic one. By bringing together aesthetically appealing, idyllic elements, one can make a little haven for oneself that protects from the outside world - a warm, personalized, and humanized nest in a world that is too cold, too disenchanted, and, perhaps, too functional.

Adolf Loos's writings, as well as those of Walter Benjamin on the interior of the nineteenth-century bourgeois home, teach us that aestheticization serves the purpose of privatizing space, making it one's own, humanizing it so that one can feel safe in it. "Man," writes Loos, "loves everything that satisfies his comfort. He hates everything that wants to draw him out of his acquired and secured position and that disturbs him" (Loos qtd. in Heynen 79; see also Loos, On Architecture). In other words, humans need a place of shelter that has the same temporality of the foreseeable, the familiar and the usual that characterizes the oasis. The collective aspect is missing here, however, as Loos is concerned with private houses and tries to explain why the architect should leave interior decoration to the occupants of the house, who need to adorn their residence with personal objects in order to feel at home. Only by being thus aestheticized and humanized can a house truly become a home: a safe, intimate haven. A cold space is thus subjectivized and given a reassuring "face." By way of illustration, we examine the "before" and "after" image of an intervention that the Lion-Descartes atelier imagines 
Bart Keunen and Sofie Verraest,

"Tell-tale Landscapes and Mythical Chronotopes in Urban Designs for Twenty-first Century Paris" page 7 of 11

CLCWeb: Comparative Literature and Culture 14.3 (2012): <http://docs.lib.purdue.edu/clcweb/vol14/iss3/4>

Thematic Issue New Work on Landscape and Its Narration. Ed. Sofie Verraest, Bart Keunen, and Katrien Bollen

in Evry, one of the new towns around Paris. The visual rhetoric of juxtaposing an inhospitable with a highly attractive environment is a tried-and-tested method in most of the dossiers. In the "before" image (Atelier Lion-Descartes 12), an uninhabited zone along the N7 is presented as a banal space that is uninviting and seemingly unfit for habitation. The image bears resemblance to well-known images of wastelands, those in-between spaces of our dilated metropolitan peripheries that are lacking in identity and human character. This landscape's only raison d'être is the fact that it is a transit zone. Its users are not at home there, but on their way. As a necessary evil for anyone who wishes to travel from one hospitable location to another, it is not a destination in itself, but an area of passage to be traversed as quickly as possible. The transients in this landscape can only be motorists, or perhaps a pedestrian who got lost. As the space is not welcoming, it is generally traversed with speed, and barely glimpsed from inside one's safe, four-wheeled mobile capsule.

This situation seems to be right up Atelier Lion-Descartes's alley: the team sets itself the "extraordinary" task of "improving the ordinary" in Paris, a motto that is restated on numerous occasions. It discusses "the necessity of restoring a human dimension in the urban" (263). The "after" image shows the result (13). From the first glance, the space already appears more hospitable. No longer simply an endless space of transit, the place is now the destination of a great number of people going home: everywhere in the image, living quarters have been put up to mark the fact that this location is now fit for habitation. The wasteland of asphalt and ill-defined extensiveness has turned into a space of safety, a personal place where people can settle down and build themselves a nest. This suggestion is powerfully evoked by the presence of a child, a defenseless creature that needs to be protected from the dangers of the outside world. The child conjures up associations with purity, naïveté, and innocence, and typically needs a warm environment sheltered from anonymity. It would be rather unsettling to see this vulnerable creature wandering in the inhospitable landscape of the first image. The Lion-Descartes group indeed points to a problem that today's Paris is facing in this respect: "the capital attracts active young people who escape the city as soon as they have had their first children" (47). Put differently, too many families perceive the urban climate as hostile to children and end up moving out of the city. For people (and especially children) to feel at home, they need to be surrounded by an aestheticized, humanized, or, in more mythical terms, "animated" or subjectivized capsule. Only if they recognize themselves in their surroundings as being animated, these surroundings can take on a capsular form. It is not just the wooden terrace, the bamboo railing and the plants on the balcony that lend the apartment in this image that ambiance of the natural, of an environment tailor-made for humans. The green panorama, too, plays a key role, and is, in a sense, part of the inhabitants' "interior."

However, the dream of tranquility, security, and familiarity - be it a collective or a private one is not the only one found in the dossiers for Greater Paris. In addition to a unified and homogeneous space, two other re-enchantments deal with creating an open, more heterogeneous space that - on a temporal level - welcomes dynamic movement and rapid, unabated change. Before discussing the individual variant that is largely determined by personal capriciousness (the chronotope of the "bazaar"), we first examine the collective time-space of the rationalized "hub." This dynamic, everfluctuating place full of potentialities is thought to play an essentially catalyzing role for the urban collectivity. Its streamlined movement of dynamic fluxes seems to give off such energy that this busy movement alone is somehow expected to speed up collective history for the better, in much the same way that, in the Grumbach vision, the Seine was expected to magically unite Paris into an oasis. Like Grumbach and Descartes, then, the atelier of Portzamparc begins by assessing the alienation that characterizes present-day Paris, which presents itself as an inhospitable "outside": "The metropolis strikes us everywhere as a labyrinth of enormity, an excess, a vertigo. ... No one understands the whole" (Agence Grumbach, Livret 133 ). While the urbanite "dreams of having access to the entire world," "he is having a hard time as soon as he leaves his lair, his little perimeter. The neighboring, the near-by, may be hostile and unsafe, the remote unknown" (Agence Grumbach, Livret 134 ). The challenge is thus to create a Paris where one feels connected to the entire world, while at the same time avoiding alienation. The first objective precludes both oasis and capsule, and requires a more centrifugal space, but one that is no less enchanting. For Portzamparc, the centrifugal is a necessary element of urbanity, but the fluxes need to be rationalized and streamlined if we are to prevent them 
from being unsettling. The group refers to these fluxes as "Hermes": the flows of goods, merchandise, and people that virtualize space. Yet, the urbanite also has a need to physically dwell in space on a daily basis without feeling utterly lost - another unavoidability, which is designated by the term "Hestia." The primary issue, then, is "to master Hermes and reconnect it with Hestia" (Atelier Portzamparc, Livret 2.177), that is, to create a space that integrates the flows of Hermes in a positive manner. It is time to "return to place, while relating it to the referents of our day and age, the networks" (Atelier Portzamparc, Livret 2.135 ).

It is time, in other words, to channel the centrifugal energy in order to create something new: a dynamic space of efficient, collective movement that everyone can partake in and feel part of: it is time for a hub. Privileged places for such a hub effect are the crucial junctions at which streams of urban energy converge: the literal transportation hubs. The Portzamparc team's key proposal for such a "metropolitan commutator" (Atelier Portzamparc, Livret 2.172 ) is a zone to be created around a new international railway station, the Gare Europe Nord, which they imagine in Aubervilliers (Atelier Portzamparc, Du Cyberespace 116-17; Une Nouvelle <http://www.linternaute.com/actualite/grandprojet/photo/grand-paris-voici-ce-qu-ont-prevu-les-architectes/une-nouvelle-gare-aaubervilliers.shtml>). This zone will be characterized by an open space: it is a "device for interconnecting different circuits" (Atelier Portzamparc, Livret 2.1 73) in a city where "every point can be hyperlinked to every other" (Atelier Portzamparc, Livret 2.1 57). Thanks to the Gare Europe Nord, Paris will be integrated in a world-wide metropolitan network: it constitutes an "interface in a network with the other metropolises of the world," a network of prosperity, or a "circuit of rich connections that form a 'rhizome'" (Le Grand Paris <http://www.lexpress.fr/diaporama/diapophoto/actualite/politique/le-grand-paris-dans-vingt-ans-en-images_745158.html?p=5>). Nevertheless, this open space remains a privileged "inside" sphere one can relate to thanks to the overall positive temporality of continuous renewal it seems to be caught up in. The atelier's starting point is that "telecommunications" and "the speed of global exchanges have modified the organizations" of the city (Atelier Portzamparc, Livret 2.1 57), which is now mainly characterized by its "dynamics and ... the economy of flows" (Atelier Portzamparc, Livret 2.1 59). If a local zone wants to flourish and grow, it should therefore establish a connection with these global economic exchanges: "space needs to regain its capacity for being a 'medium' of life by allowing the system to continuously improve its efficiency" (Atelier Portzamparc, Livret 2.1 59). In this sense, the Gare Europe Nord, and the entire lucrative zone that is to develop around it, constitutes one of those places where innovation and improvement reach ever higher levels, and the collective future of Paris is being created. The Gare integrates the city of Paris into the linearly progressing temporality of the global market. The affective atmosphere such a hub seems to breathe is a kind of euphoria of growth that suggests a world of inexhaustible potential. If Portzamparc's understanding of a rhizomatic economy of interconnected "flows" is radically different from Grumbach's depiction of a circular economy, this difference is to be traced back to the divergent chronotopic dreams these urbanist teams seek to convey. Whereas Grumbach attempts to seduce Parisians by promising a dreamt-of calm and peaceful community, Portzamparc's ideal is one of collective prosperity-through-dynamism.

A comparable dynamic expressiveness emanates from the Parisian universe imagined by the Equipe Nouvel - Duthilleul - Cantal-Dupart, yet, in this case, it is not the collectivity, but the individual that is concerned. To conceptualize this final modern myth, we make use of sociologist Peter Langer's spatial metaphor of the bazaar: "a place of astonishing richness of activity and diversity unparalleled in nonurban areas; a market, a fair, a place of almost infinite exploration and opportunity, a center of exchange; unique combinations of social affiliations and lifestyles; a liberation from the one-dimensionality of the small town" (Langer 100). Like the hub, the bazaar is a dynamic, heterogeneous, and unforeseeable space, but its interactions and movements are no longer rationalized into a collective progression and accumulation. They are, rather, thought to be valuable in themselves, for those who experience them on the spot. The dynamism central to this chronotope resides in the highly situational encounter of a multitude of arbitrary elements, which occasionally creates a spark. The encounter of disparate elements is believed to have a chemistry of its own, and to produce an experience in which the on-the-spot impulse, the whim, the surprising, the creative, and the adventurous occupy center stage, stimulating Parisians to continuously rediscover their city. 
Bart Keunen and Sofie Verraest,

"Tell-tale Landscapes and Mythical Chronotopes in Urban Designs for Twenty-first Century Paris" page 9 of 11

CLCWeb: Comparative Literature and Culture 14.3 (2012): <http://docs.lib.purdue.edu/clcweb/vol14/iss3/4>

Thematic Issue New Work on Landscape and Its Narration. Ed. Sofie Verraest, Bart Keunen, and Katrien Bollen

The dynamic encounters of the bazaar do not need to be rationalized and rendered efficient for the collective body in order to create a surplus value. It is sufficient for each actor in space to follow his/her own pre-rational impulses and urges at random. In Nouvel's terms, places "must be paroxysmic in order to attain intensity" (Equipe Nouvel, Livret 2 39). If they are, every moment spent in the streets potentially results in an intense experience. The extensive temporality of the collectivity is thus replaced by a subjective time of intensity. This is why the Nouvel group believes that the means of transport in the city should offer "journeys" rather than simple "movements": "Only the journey is exceptional and enchanting, while the route is repetitive and banalizing" (Equipe Nouvel, Livret 1 206). The atelier sets out to describe these "trails" in a considerably exalted manner: "the trail presents itself as the account of an exploration, a more or less adventurous story that does not follow the great routes, but the more secret, mysterious, less banal paths. The trail invites to dream of adventure, of landscapes, of discoveries, and vicissitudes" (Fleischer 6).

It is, among other things, owing to the omnipresence of the arts that the city will assume this adventurous aspect. Daniel Buren, the artist with whom the group collaborated, explains that Paris urgently needs to attract "hundreds" of artists in order to turn the entire public space into a "gigantic workplace, which would quite simply allow the entire city and its spirit to change profoundly" (3). Paris would fall under the spell of art and adventure; one would be able to move through the city in the manner of the Surrealists. Equipe Nouvel maintains that the proposed artistic experiences in Paris "offer collective 'enchantments', and liberate us from reason. The creations ... usually propose expressions in movement ... The accompanying emotional charge leaves an indelible imprint" (Equipe Nouvel, Livret 1220 ) This is also what lies behind the wish to, quite literally, once again turn Paris into the City of Lights. At night, too, the arts should rule the city: the bazaar ought to reclaim the night, by dazzling Parisians with a multitude of light sculptures. By day as by night, the city should present itself as an immense sculpture, and have an overall revitalizing effect (Gambling

<http://chunnelvision.files.wordpress.com/2009/05/imagenouvel_cb237.jpg>). It is also in relation to the bazaar's intensity that one should interpret the group's glorification of skyscrapers and Parisian verticality: "The model of any tower should be the Tower of Babel: a little city where diverse parlances encounter one another in a living polyphony of languages, professions, activities, and ages" (Fleischer 4). Paris would thus acquire a physiognomy that prompts adventure, interrogation, and discovery this very specific form of urbanity that constitutes the bazaar. Only then "the open air, the air of the city and of the outside, acts as a fully-fledged dramatic force" (Equipe Nouvel, Livret 1 219).

A number of conclusions can be drawn at this point. Starting from Cassirer's writings on the mythical-magical mode of experience, and the idea that aesthetic affects can be considered its secular heirs, this article has examined the extent to which architectural designs and urbanist visions are influenced by mythical remainders. Even if the scope of this paper allowed for only four case studies, the photographic, schematic, and textual material of each of the ten designs for Greater Paris shows glimpses of a rhetoric in which affectively alluring representations conjure up a "mythologizing" image of the Parisian landscape. In spite of all anti-utopian claims to a no-nonsense approach, the urbanist teams turn out to be susceptible to a certain re-enchantment of the contemporary city and often depict experiential spaces that are given a singular chronotopic coherence. In an attempt to seduce the public, they portray inviting, secure, stimulating, or otherwise alluring spaces. Important in this respect is the mythical way (in the Cassirerian sense) in which these alluring zones are given shape: as extraordinary "inside" spaces or enclaves that maintain a dialectical relationship with an "outside" that is perceived as mediocre. Given that the concrete affective expressiveness or "physiognomy" of such images largely depends on their specific spatiotemporal structure, they are particularly wellsuited for a Cassirerian-Bakhtinian reading. While the oasis chronotope presents an integrated Paris in which the collectivity's concerted actions in harmony with nature make up a smooth whole, the equally idyllic capsule offers individual retreat away from urban chaos. Diametrically opposed to such harmonious images, which exude an atmosphere of containability, security, and reassurance, are the dynamic, open spaces of the hub and the bazaar embodying the excitement of change, unpredictability, and the new. In the first case, this dynamism is believed to be rationalized into a collective progress; in the second, its added value is thought to arise from the accidental encounter of individual Parisians who give free rein to their pre-rational, creative impulses. Variations in temporal 
Bart Keunen and Sofie Verraest,

"Tell-tale Landscapes and Mythical Chronotopes in Urban Designs for Twenty-first Century Paris" page 10 of 11 CLCWeb: Comparative Literature and Culture 14.3 (2012): <http://docs.lib.purdue.edu/clcweb/vol14/iss3/4> Thematic Issue New Work on Landscape and Its Narration. Ed. Sofie Verraest, Bart Keunen, and Katrien Bollen

and spatial structures thus allow for divergent landscape images, each with their own outspoken identity.

Rather than as some sort of catalogue of design strategies, this article considers the four stereotypical immersive narratives under consideration as aesthetic ways of re-enchanting today's world - stories about spatial experience that appeal to the modern urbanite. Far from seeking to unmask urban projects as mere mythical fantasies of a caricature-like simplicity, we propose a method of reading that deconstructs urban spaces in order to reveal their unavoidable pre-rational aspects. For modern mythology constitutes a fundamental element of our (three-layered) spatial perception and conception, which needs to be distinguished from purely empirical cause-effect analyses of the actual urban reality. Even in our "enlightened," scientific, and rationalized times, some "return of the repressed" - some "phantasmagoric" re-enchantment of reality, as Walter Benjamin would have it subsists. Especially in light of the scale and social urgency of an urbanist consultation like Sarkozy's, it would be useful to discern such phantasmagorical elements from the more pragmatic, conditional and analytic ones. For all his claims that, in a modern world without ready-made recipes for life, humankind needs to be able to dream, Benjamin also believed that it is imperative for us to wake up afterwards.

\section{Works Cited}

Agence Grumbach \& associés. Livret chantier 1 (2008): <http://www.legrandparis.culture.gouv.fr/documents/GRUMBACH_Livret_chantier_1.pdf>.

Agence Grumbach \& associés. Livret chantier 2 (2009): <http://www.legrandparis.culture.gouv.fr/documents/GRUMBACH_Livret_chantier_2.pdf>.

Atelier Lion-Groupe Descartes. Livret chantier 1 \& 2 (2009): <http://www.legrandparis.culture.gouv.fr/documents/DESCARTES_Livret_chantier_1_2.pdf>.

Atelier Portzamparc. Du Cyberespace vers l'espace physique. Un défi pour la métropole (2009): $<$ http://urbanisme.u-pec.fr/actualites/synthese-du-projet-portzamparc-iup-319058.kjsp?RH=1256215581693>.

Atelier Portzamparc. Livret chantier 1 (2008): <http://www.legrandparis.culture.gouv.fr/documents/PORTZAMPARC_Livret_chantier_1.pdf>.

Atelier Portzamparc. Livret chantier 2.1 (2009): $<$ http://www.legrandparis.culture.gouv.fr/documents/PORTZAMPARC_Livret_chantier_2_1.pdf>.

Bakhtin, Mikhail. "Forms of Time and of the Chronotope in the Novel." The Dialogic Imagination. By Mikhail Bakhtin. Trans. Caryl Emerson and Michael Holquist. Austin: U of Texas P, 1981. 84-258.

Bartetzky, Arnold, and Marc Schalenberg. "Shapes of Happiness: Planning Concepts and Their Manifestations in Urban Form." Urban Planning and the Pursuit of Happiness. Ed. Arnold Bartetzky and Marc Schalenberg. Berlin: Jovis, 2009. 7-17.

Barthes, Roland. S/Z. Paris: Seuil, 1970.

Bauman, Zygmunt. Liquid Modernity. Cambridge: Polity P, 2000

Benjamin, Walter. The Arcades Project. Trans. Howard Eiland and Kevin McLaughlin. Cambridge: Harvard UP, 1999.

Brandist, Craig. "Bakhtin, Cassirer and Symbolic Forms." Radical Philosophy 85 (1997): 20-27.

Bruner, Jerome. Actual Minds, Possible Worlds. Cambridge: Harvard UP, 1986.

Buren, Daniel. "Arts." Livret chantier 2. Ed. Equipe Nouvel - Duthilleul - Cantal-Dupart (2009): <http://www.legrandparis.culture.gouv.fr/documents/NOUVEL-AREP-MCD_Livret_chantier_2.pdf>.

Campbell, Joseph. The Hero with a Thousand Faces. Princeton: Princeton UP, 1968.

Cassirer, Ernst. Mythical Thought. Trans. Ralph Manheim. New Haven: Yale UP, 1955.

Cassirer, Ernst. The Phenomenology of Knowledge. Trans. Ralph Manheim. New Haven: Yale UP, 1965.

Equipe Nouvel - Duthilleul - Cantal-Dupart. Livret chantier 1 (2008): <http://www.legrandparis.culture.gouv.fr/documents/NOUVEL-AREP-MCD_Livret_chantier_1.pdf>.

Equipe Nouvel - Duthilleul - Cantal-Dupart. Livret chantier 2 (2009): <http://www.legrandparis.culture.gouv.fr/documents/NOUVEL-AREP-MCD_Livret_chantier_2.pdf>.

Fleischer, Alain. "Textes." Livret chantier 2. Ed. Equipe Nouvel - Duthilleul - Cantal-Dupart (2009): <http://www.legrandparis.culture.gouv.fr/documents/NOUVEL-AREP-MCD_Livret_chantier_2.pdf>.

Herman, David. Basic Elements of Narrative. Oxford: Wiley-Blackwell, 2009.

Heynen, Hilde. Architecture and Modernity: A Critique. Cambridge: MIT P, 1999.

Jansen, Bregit, and Olof van de Wal, eds. "Van de redactie." Stedenbouw als Strategie. De Transformatie van de Bestaande Stad. Ed. Stadscahiers. Amsterdam: SUN, 2010. 6-10.

Keunen, Bart. Time and Imagination: Chronotopes in Western Narrative Culture. Evanston: Northwestern UP, 2011.

Langer, Peter. "Sociology. Four Images of Organized Diversity: Bazaar, Jungle, Organism, and Machine." Cities of the Mind: Images and Themes of the City in the Social Sciences. Ed. Lloyd Rodwin and Robert Hollister. New York: Plenum P, 1989. 97-117.

Le Grand Paris dans vingt ans en images (2009): <http://www.lexpress.fr/diaporama/diapophoto/actualite/politique/le-grand-paris-dans-vingt-ans-en-images_745158.html?p=5>.

Loos, Adolf. On Architecture. Trans. Michael Mitchell. Riverside: Ariadne P, 2002. 
Bart Keunen and Sofie Verraest,

"Tell-tale Landscapes and Mythical Chronotopes in Urban Designs for Twenty-first Century Paris" page 11 of 11

CLCWeb: Comparative Literature and Culture 14.3 (2012): <http://docs.lib.purdue.edu/clcweb/vol14/iss3/4>

Thematic Issue New Work on Landscape and Its Narration. Ed. Sofie Verraest, Bart Keunen, and Katrien Bollen

Lotman, Yuri. "The Origin of Plot in the Light of Typology." Poetics Today 1.1-2 (1979): 161-84.

Lyotard, Jean-François. La Condition postmoderne. Rapport sur le savoir. Paris: Minuit, 1979.

O'Toole, Roger. "Salvation, Redemption and Community: Reflections on the Aesthetic Cosmos." Sociology of Religion 57.2 (1996): 127-48.

Gambling on le Grand Paris (2009): <http://chunnelvision.files.wordpress.com/2009/05/imagenouvel_cb237.jpg> .

Poole, Brian. "Bakhtin and Cassirer: The Philosophical Origins of Bakhtin's Carnival Messianism." Bakhtin: Studies in the Archive and Beyond. Ed. Peter Hitchcock. Special issue South Atlantic Quarterly 97 (1998): 537-78.

Ryan, Marie-Laure. Narrative as Virtual Reality: Immersion and Interactivity in Literature and Electronic Media. Baltimore: Johns Hopkins UP, 2001.

Ryan, Marie-Laure. "Cognitive Maps and the Construction of Narrative Space." Narrative Theory and the Cognitive Sciences. Ed. David Herman. Stanford: Center for the Study of Language and Information, 2003. 214-42.

Todorov, Tzvetan. "La Grammaire du récit." Languages 12 (1968): 94-102.

Une Métropole géante de Paris au Havre (2009): < http://www.linternaute.com/actualite/grandprojet/photo/grand-paris-voici-ce-qu-ont-prevu-les-architectes/une-metropole-geante-de-paris-auhavre.shtml>.

Une Nouvelle gare à Aubervilliers (2009): <http://www.linternaute.com/actualite/grand-projet/photo/grand-parisvoici-ce-qu-ont-prevu-les-architectes/une-nouvelle-gare-a-aubervilliers.shtml>.

Author's profile: Bart Keunen <http://www.gust.ugent.be/bartkeunen> teaches comparative literature at Ghent University. His fields of interest in research include urban studies, genre criticism, literary historiography and literary sociology. Keunen's recent book publications include: Time and Narrative: Chronotopes in Western Narrative Culture (2011) and the edited volumes Literature and Society: The Function of Literary Sociology in Comparative Literature (2001, with Bart Eeckhout) and The Urban Condition: Space, Community, and Self in the Contemporary Metropolis (1999; with GUST). Since 2000, he is one of the co-directors of the Ghent Urban Studies Team <http://www.gust.ugent.be/>. E-mail: <bart.keunen@ugent.be>

Author's profile: Sofie Verraest <http://www.gust.ugent.be/sofieverraest> is working towards her doctorate in the Department of General and Comparative Literature Studies at Ghent University. Within the framework of Ghent Urban Studies Team <http://www.gust.ugent.be/> she works on a cross-disciplinary project funded by the Flemish Fund for Scientific Research. In her dissertation, Verraest proposes a narratological analysis of phantasmagorical spaces in urban imagination since World War II, both in urbanism and literature. E-mail: <sofie.verraest@ugent.be> 